\title{
David Oliver: The health secretary and upstanding nurses
}

\section{David Oliver consultant in geriatrics and acute general medicine}

Berkshire

I'm worried about what our health secretary's remarks at the chief nursing officers' conference reveal about his understanding of the modern health service. The full text of Matt Hancock's speech can be found on the government's website, ${ }^{1}$ and he made some valid points about recognising the skills of our nursing workforce.

Sadly, he also said: "I find it shocking that, in my grandmother's day, nurses were expected to stand up when a doctor entered the room. And worse, I find that's still the case in some antiquated, archaic corners of the NHS. I want it to stop. If anything, it should be doctors standing up for nurses. Because who runs a hospital at 2 am in the morning? Who keeps the show on the road?"

The reaction to these remarks on social media made it into the national press. ${ }^{23}$ It was hard to find a doctor or nurse still practising who had seen or heard of such behaviour or expectations. Not least because nurses are so overstretched that sitting down in the first place would be a luxury.

We should debate hierarchies and professional power in healthcare-but in the context of modern roles and culture, not the kind depicted in Doctor in the House in the 1950s.

As well as bemusing the nurses, Hancock managed both to offend doctors working overnight in hospitals and to look as though he was trying to drive a wedge between the two biggest clinical professions. Doctors and a range of allied health professionals are very much available on call or working on site overnight, and Hancock's remarks echoed his predecessor Jeremy Hunt's inaccurate views on weekend and evening working. ${ }^{45}$

In our political system it's rare for ministers of state to have serious experience or credibility in the public service for which they're accountable. Even competent ministers will take a year or more to get up to speed with some content expertise by studying, listening, and learning. Misspeaking on public platforms is understandable among ministers new to their brief: we're all human and fallible.
Hancock has been in his post for eight months, so one might think that basic errors could be avoided with the help of senior officials, staff in his private office, and communications teams, with input from doctors and nurses in government bodies. Yet he's already managed a few gaffes, such as publicly favouring Babylon Health among a sea of health tech providers ${ }^{6}$ or sending a tweet appearing to claim that deaths from sepsis were all preventable, ${ }^{7}$ when most are not, ${ }^{8}$ and having to backtrack semi-apologetically online.

Nurses are so overstretched that sitting down in the first place would be a luxury

The real shame of his rhetorical trip to an NHS no one seemed to recognise was that it detracted from the points he and others made about the serious challenges to nursing and the need for solutions, some of which were set out at the same conference by the new chief nursing officer, Ruth May. ${ }^{9}$

I'm glad that both Hancock and May recognised the need to boost the engagement and influence of nurses at every level of NHS leadership, from local services to Whitehall. I'm glad that he recognised the crucial contribution nurses make, their high level skills that go well beyond outdated conceptions, and their key role in managing and leading services.

But the single most "mission critical" challenge is workforce shortages, which independent analyses have shown will get worse before they get better. Around 40000 nursing positions are unfilled in England-one in eight. ${ }^{10}$ Numbers of posts in health visiting, community nursing, and learning disability nursing have fallen. That's what Hancock and his government should focus on tackling.

He should stand up for nurses with concrete action and investment, not bizarre rhetorical fantasies based on a long gone age.

Competing interests: See www.bmj.com/about-bmj/freelance-contributors. Provenance and peer review: Commissioned; not externally peer reviewed. 
1 Department of Health and Social Care, Hancock M. Nurses are mission-critical to culture change in the NHS. 14 Mar 2019. https://www.gov.uk/government/speeches/nurses-aremission-critical-to-culture-change-in-the-nhs.

2 Matt Hancock mocked after saying that some nurses still stand up when a doctor enters a room, as NHS worker quips "it isn't Downton Abbey." Telegraph 2019 Mar 14. https:// www.telegraph.co.uk/news/2019/03/14/matt-hancock-mocked-saying-nurses-still-standdoctor-enters/.

3 Matthews-King A. Health secretary prompts ridicule after claiming NHS nurses stand up when doctors enter room. Independent 2019 Mar 14. https://www.independent.co.uk/ news/health/health-secretary-matt-hancock-nurse-stand-doctors-nhs-a8823016.html.

4 Oliver D. David Oliver: Seven day service standards in NHS hospitals: thorny problem or blooming success?BMJ 2017;359:j5552. 10.1136/bmj.j5552 29208735

5 Matthews-King A. Jeremy Hunt's seven day working targets "not linked" to fewer weekend deaths, says study. Independent 2017 Nov 9. https://www.independent.co.uk/news/health/ jeremy-hunt-nhs-seven-day-working-targets-doctors-nurses-hospitals-weekend-deathsstudy-a8044521.html.
6 Syal R. Matt Hancock accused of breaching code over GP app endorsement. Guardian 2018 Nov 30 . https://www.theguardian.com/politics/2018/nov/30/matt-hancock-accusedof-breaching-code-over-gp-app-endorsement.

7 Hancock M. Twitter 2019 Mar 13. https://twitter.com/MattHancock/status/ 1105736732597723137.

8 Field P. How preventable is sepsis-related death? Medical News Today 2019 Mar 12. https://www.medicalnewstoday.com/articles/324687.php.

9 Mitchell G. Ruth May pledges to tackle "unacceptable" race inequalities. Nurs Times 2019 Mar 14. https://www.nursingtimes.net/news/workforce/ruth-may-pledges-to-tackleunacceptable-race-inequalities/7028224.article.

10 King's Fund. The health care workforce in England: make or break? 15 Nov 2018. https: //www.kingsfund.org.uk/publications/health-care-workforce-england.

Published by the BMJ Publishing Group Limited. For permission to use (where not already granted under a licence) please go to http://group.bmj.com/group/rights-licensing/ permissions 